\title{
Effect of seasonal changes in Leydig cell number on the volume of smooth endoplasmic reticulum in Leydig cells and intratesticular testosterone content in stallions
}

\author{
L. Johnson* and D. L. Thompson, Jr† \\ Department of Cell Biology and Anatomy, The University of Texas Health Science Center at \\ Dallas, Dallas, Texas 75235, and $\uparrow$ Department of Animal Science, Louisiana Agricultural \\ Experiment Station, Louisiana State University Agricultural Center, Baton Rouge, \\ Louisiana 70803, U.S.A.
}

\begin{abstract}
Summary. Testes from 47 adult (4-20 years) stallions obtained in November-January (non-breeding season) and 41 adult stallions obtained in May-July (breeding season) were perfused with glutaraldehyde, placed in osmium and embedded in Epon 812. Percentage Leydig cell cytoplasm or nuclei in the testis was determined by point counting of $0.5 \mu \mathrm{m}$ sections under bright-field microscopy. Testes from 6 randomly selected horses per season were processed for electron microscopy. The volume (ml) of SER/ testis was calculated from the \% SER in the cytoplasm \% Leydig cell cytoplasm, and parenchymal volume. Number of Leydig cells was calculated from the \% nuclei, parenchymal volume, histological correction factor, and volume of single nucleus. Intratesticular testosterone content was determined from the contralateral testis by radioimmunoassay. The volume of $\mathrm{SER} / \mathrm{g}$ and testosterone/g tended to be higher in the breeding than non-breeding season. Leydig cell number/g, volume of SER/testis, testosterone/testis, and Leydig cell number/testis were significantly greater in the breeding than in the non-breeding season. Volume of SER/testis and testosterone/testis were related significantly to the cell number/testis, and SER/testis was related $(P<0.05)$ to testosterone/testis. These results emphasize the importance of seasonal changes in the number of Leydig cells on the amount of SER available to produce testosterone and on testosterone content/testis in the stallion.
\end{abstract}

\section{Introduction}

Stallions are seasonal breeders in that they produce more spermatozoa in the summer (breeding season) than in the winter (non-breeding season; Johnson, 1985; Johnson \& Thompson, 1983). During the breeding season, serum concentrations of testosterone (Berndtson et al., 1974; Wiesner \& Kirkpatrick, 1975; Johnson \& Thompson, 1983), luteinizing hormone (LH; Thompson et al., 1977; Johnson \& Thompson, 1983) and prolactin (Thompson et al., 1986) are highest in stallions. The number of Leydig cells per testis is greater in the breeding than in the non-breeding season and the size of the Leydig cell population fluctuates with the yearly reproductive cycle of the stallion (Johnson \& Thompson, 1986): the number of Leydig cells per testis was significantly correlated $(r=0.81 ; P<0.01)$ with total volume of Leydig cells per testis.

In contrast to other seasonal breeders, such as the rock hyrax (Neaves, 1973), roebuck (Short \& Mann, 1966), and lump-nosed bat (Pearson et al., 1952), the size of individual Leydig cells in stallions was similar between seasons (Johnson \& Thompson, 1986). It is not known whether similar size of

\footnotetext{
*Present address: Department of Veterinary Anatomy, College of Veterinary Medicine, Texas Agricultural Experiment
} Station, Texas A\&M University, College Station, TX 77843-4458, U.S.A. 
individual Leydig cells between seasons is consistent with similar amounts of smooth endoplasmic reticulum (SER) or whether organelle content of Leydig cells is altered by season. Amongst species, Leydig cell mass (Ewing et al., 1979) did not reflect the amount of SER, values of which almost totally explained the variation in testosterone secretion in vitro (Zirkin et al., 1980). Therefore, in the stallion, or within a given species, the extent that seasonal variation in Leydig cell volume reflects variation in SER volume or intratesticular testosterone content is unknown. The objective of this study was to determine the effect of seasonally altered Leydig cell number on the volume of SER and intratesticular testosterone content.

\section{Materials and Methods}

Animals. Testes from adult (4-20 years of age) horses were obtained from a slaughter house within a 3-month period representing the breeding season (May-July, $N=41$ ) or the non-breeding season (November-January, $N=47$ ). Only horses from light-weight breeds, in good body condition, and having a smooth hair coat were used. Histological examination showed that all stallions had active spermatogenesis. Age of stallions was determined by eruption and wear patterns of incisors. Within $15 \mathrm{~min}$ of death, a portion of each testis was perfused for $20 \mathrm{~min}$ through a branch of the testicular artery accessible within the tunica albuginea with $2 \%$ glutaraldehyde in $100 \mathrm{~mm}$-cacodylate buffer (Johnson \& Neaves, 1981). Five pieces of testis obtained from the locally-fixed, equatorial region were placed in the same fixative and stored at $5^{\circ} \mathrm{C}$ until being placed in $1 \% \mathrm{OsO}_{4}$ in the same buffer for $1 \mathrm{~h}$. This sampling method is appropriate as uniformity among different regions of the horse testis has been described (Gebauer $e$ t al., 1974; Johnson $e t$ al., 1978). Tissues were dehydrated in ethanol and embedded in Epon 812. Embedded tissues were sectioned at $0.5 \mu \mathrm{m}$ for bright-field microscopy or thin sectioned for electron microscopy as previously described (Johnson \& Neaves, 1981; Johnson \& Thompson, 1986).

Stereology. The number of Leydig cells and volume of Leydig cell cytoplasm per testis were determined for all stallions by stereological procedures using Chalkley's (1943) point counting of $0.5 \mu \mathrm{m}$ sections and nuclear volume estimates in $20 \mu \mathrm{m}$ Epon sections as previously described (Johnson \& Neaves, 1981; Johnson \& Thompson, 1986). Testes from 6 randomly selected stallions ( $4-14$ years; $8 \pm 2$ years) in the non-breeding and from 6 stallions (4-19 years; $9 \pm 2$ years) in the breeding season were processed for transmission electron microscopy (Johnson \& Thompson, 1986). The difference in age between seasons was not statistically significant $(P>0.05)$. Electron micrographs were taken randomly at predetermined locations on the grids. Electron micrographs (14-22 per stallion; 122 for non-breeding and 115 total micrographs for breeding season animals) were analysed at $\times 32300$ magnification for the volume density (percentage) of cytoplasm occupied by SER, rough endoplasmic reticulum (RER), mitochondria, lysosomes (also included proxisomes), lipid, swirled membrane, or other cytoplasmic components (such as ribosomes and cytosol). Precision of duplicate estimates of \% SER made on separate sets of micrographs for each horse was estimated at $2.6 \%$ coefficient of variation. The volume of SER per testis was determined by multiplying the volume of Leydig cell cytoplasm per testis previously determined for all the stallions in each season (Johnson \& Thompson, 1986) by the volume density of SER in the Leydig cell cytoplasm.

Endocrinology. Serum concentrations of follicle-stimulating hormone (FSH), luteinizing hormone (LH), testosterone, and prolactin were determined by radioimmunoassay as described previously (Johnson \& Thompson, 1983; Thompson et al., 1986; Thompson \& Johnson, 1987). It has been shown previously that variation in serum LH or testosterone concentrations amongst stallions is largely relative to the temporal variation of an individual stallion's values around his daily mean (Thompson et al., 1985). Thus, single blood samples collected at the time of slaughter appear to be adequate to predict average daily concentrations during the breeding and non-breeding seasons. Intratesticular testosterone concentration was determined by radioimmunoassay (Gay \& Kerlan, 1978). Portions of testis were homogenized in methanol $(50 \mu \mathrm{g}$ tissue $/ \mathrm{ml})$. Duplicate $25-\mu \mathrm{l}$ samples were dried under a stream of air and then reconstituted in assay buffer. Specificity of the assay for testosterone was confirmed by (1) demonstration of parallel inhibition curves for various amounts of extract and authentic testosterone, (2) demonstration of a single peak of immunoreactivity coincident with testosterone in the assay of extracts fractionated in a thin-layer chromatography (t.l.c.) system (silica gel-impregnated glass-fibre strips from Gelman Scientific and eluted with ether:ethanol, $96: 4 \mathrm{v} / \mathrm{v}$ ) that separated testosterone, androst-4-ene-3,17-dione and $5 a$-dihydrotestosterone, and (3) comparison of values obtained for 6 testes assayed as described above $(0.41 \pm 0.20 \mathrm{mg} / \mathrm{g})$ with those for the same homogenates after t.l.c. purification $(0.48 \pm 0.23 \mathrm{mg} / \mathrm{g} ; r=0.92)$ after correction for procedural losses.

Statistical analysis. Differences between seasons were tested for significance by the $t$ test (Sokal \& Rohlf, 1969). Correlation coefficients were tested for significance as described by Sokal \& Rohlf (1969).

\section{Results}

Although there was a trend for higher serum concentrations of $\mathrm{LH}, \mathrm{FSH}$, and testosterone in the breeding season, these values were not statistically different from those in the non-breeding season 
Table 1. Effect of season on the endocrine status, number of Leydig cells, volume of Leydig cell cytoplasm, and volume of SER in stallions

\begin{tabular}{|c|c|c|c|}
\hline & \multicolumn{2}{|c|}{ Season } & \multirow[b]{2}{*}{ Significance } \\
\hline & Non-breeding & Breeding & \\
\hline $\begin{array}{l}\text { No. of stallions } \\
\text { Age (years) } \\
\text { Testicular parenchymal weight (g) }\end{array}$ & $\begin{array}{l}\quad 47 \\
9 \cdot 0 \pm 0 \cdot 8 \\
126 \pm 6\end{array}$ & $\begin{array}{l}41 \\
9 \cdot 8 \pm 0 \cdot 9 \\
163 \pm 7\end{array}$ & $\begin{array}{c}\text { NS } \\
P<0.01\end{array}$ \\
\hline $\begin{array}{l}\text { Serum FSH }(\mathrm{ng} / \mathrm{ml}) \\
\text { Serum prolactin }(\mathrm{ng} / \mathrm{ml}) \\
\text { Serum LH }(\mathrm{ng} / \mathrm{ml}) \\
\text { Serum testosterone }(\mathrm{pg} / \mathrm{ml})\end{array}$ & $\begin{array}{l}104 \pm 10 \\
2 \cdot 1 \pm 0 \cdot 3 \\
24 \pm 5 \\
300 \pm 36\end{array}$ & $\begin{array}{l}134 \pm 14 \\
6 \cdot 0 \pm 0 \cdot 4 \\
37 \pm 6 \\
402 \pm 40\end{array}$ & $\begin{array}{l}\text { NS } \\
P<0 \cdot 01 \\
\text { NS } \\
\text { NS }\end{array}$ \\
\hline $\begin{array}{l}\text { Intratesticular testosterone (mg) } \\
\text { Per g tissue } \\
\text { Per testis }\end{array}$ & $\begin{array}{l}0.58 \pm 0.08 \\
77 \pm 12\end{array}$ & $\begin{array}{l}0.70 \pm 0.08 \\
112 \pm 12\end{array}$ & $\begin{array}{l}\text { NS } \\
P<0.05\end{array}$ \\
\hline $\begin{array}{l}\text { Leydig cell number } \\
\text { Per } g \text { parenchyma }\left(\times 10^{-6}\right) \\
\text { Per testis }\left(\times 10^{-9}\right)\end{array}$ & $\begin{array}{l}21 \pm 1 \\
2 \cdot 6 \pm 0 \cdot 2\end{array}$ & $\begin{array}{c}24 \pm 1 \\
4 \cdot 0 \pm 0 \cdot 2\end{array}$ & $\begin{array}{l}P<0.05 \\
P<0.01\end{array}$ \\
\hline $\begin{array}{l}\text { Volume of Leydig } \\
\text { cell cytoplasm (ml) }\end{array}$ & $14.2 \pm 0.9$ & $20 \cdot 9 \pm 1 \cdot 7$ & $P<0.01$ \\
\hline $\begin{array}{l}\text { Volume of SER } \\
\text { Per } g(\mu \mathrm{l}) \\
\text { Per testis }(\mathrm{ml})\end{array}$ & $\begin{array}{c}89 \pm 4 \\
11 \cdot 1 \pm 0 \cdot 7\end{array}$ & $\begin{array}{c}102 \pm 7 \\
17 \cdot 0 \pm 1 \cdot 4\end{array}$ & $\begin{array}{c}\text { NS } \\
P<0.01\end{array}$ \\
\hline
\end{tabular}

Values are mean \pm s.e.m.

Table 2. Volume density (\%) of various components in Leydig cell cytoplasm

\begin{tabular}{lcl}
\hline & \multicolumn{2}{c}{ Season } \\
\cline { 2 - 3 } Component & Non-breeding & Breeding \\
\hline SER & $78.1 \pm 3.8$ & $81.3 \pm 1.6$ \\
RER & $1.24 \pm 0.26$ & $1.01 \pm 0.22$ \\
Mitochondria & $11.2 \pm 0.7$ & $9.9 \pm 0.9$ \\
Lysosome & $1.33 \pm 0.30$ & $1.18 \pm 0.20$ \\
Lipid & $0.05 \pm 0.02$ & $0.16 \pm 0.05$ \\
Swirled membrane & $1.11 \pm 0.22$ & $0.88 \pm 0.09$ \\
Other components & $7.0 \pm 3.6$ & $5.6 \pm 1.8$ \\
\hline
\end{tabular}

Values are mean \pm s.e.m.

No difference $(P>0.05)$ was found in the \% Leydig cell cytoplasm occupied by any given component in 6 randomly selected stallions from each season.

(Table 1). Prolactin concentrations in serum were greater $(P<0.01)$ in the breeding than nonbreeding season. Intratesticular testosterone concentration tended to be higher in the breeding than in the non-breeding season, but there was no significant difference. Given heavier testicular parenchyma in the breeding season, the total amount of testosterone per testis was greater $(P<0.05)$ in the breeding than non-breeding season (Table 1$)$.

The number of Leydig cells per g parenchyma was slightly but significantly greater in the breeding season (Table 1). The number of Leydig cells per testis was $53 \%$ greater $(P<0.01)$ in the breeding than non-breeding season. When all horses in both seasons were combined, intratesticular testosterone content was significantly $(P<0.01)$ related $(r=0.46)$ to the number of Leydig cells per testis. 


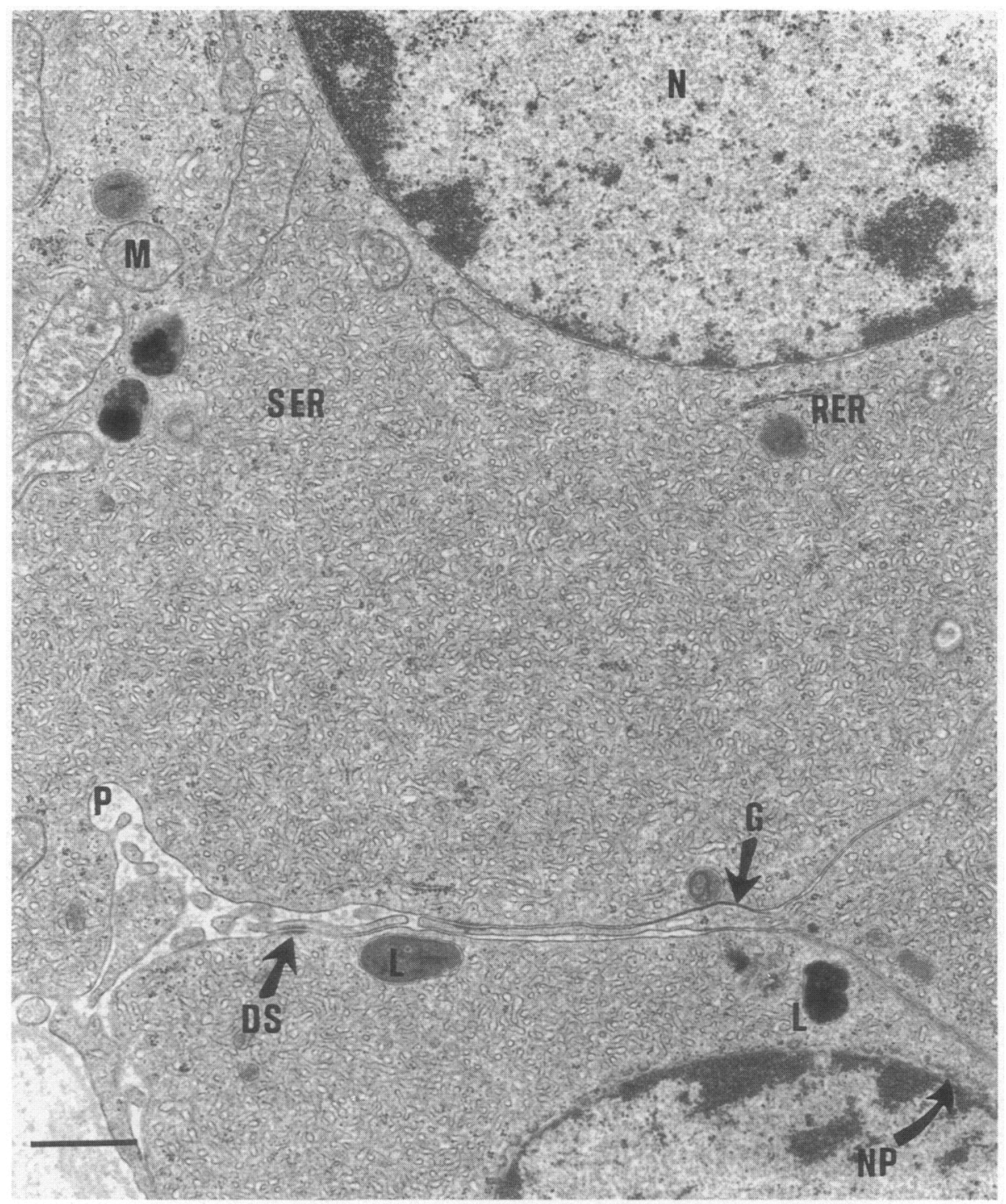

Fig. 1. Electron micrograph of Leydig cells in the stallion during the breeding season, and also characteristic of the non-breeding season. Cytoplasm contains an abundance of branched, tubular profiles of smooth endoplasmic reticulum (SER). Polyribosomes and profiles of rough endoplasmic reticulum (RER) were present but not in abundance. Mitochondria (M) with their characteristic tubular cristae usually formed clusters but were largely surrounded by SER. Secondary lysosomes (L) in various degrees of development into lipofuscin granules are present. The nucleus $(\mathrm{N})$ is largely euchromatic with heterochromatin clumps near the nuclear envelope where numerous nuclear pores (NP) are found. At the free surface of cells, the plasma membrane (P) forms microvilli. At surfaces where adjacent Leydig cells touch, gap junctions (G) and desmosomes (DS) are found. Bar $=1 \mu \mathrm{m}$.

Based on a randomly selected subset of 6 stallions per season, there was no seasonal difference in any cytoplasmic component of Leydig cells (Table 2). Figure 1 illustrates the abundance of SER in Leydig cells of adult stallions in both seasons. In both seasons, SER constituted about $80 \%$ of Leydig cell cytoplasm, and lipid constituted only a small volume density of Leydig cell cytoplasm 
(Table 2). Given similar volume density of SER between seasons, the volume of SER per g was not significantly greater in the breeding than in the non-breeding season (Table 1). However, with heavier testes in the breeding season, the volume of SER per testis was greater $(P<0.01)$ in the breeding season than in the non-breeding season.

The volume of SER per testis was significantly related to hormone concentrations and especially to the number of Leydig cells. The SER volume per testis was significantly correlated with serum concentrations of prolactin $(r=0.31 ; P<0.01)$, LH $(r=0.22 ; P<0.05)$ and testosterone $(r=0.29 ; P<0.05)$ and with intratesticular testosterone content $(r=0.41 ; P<0.01)$. The SER volume per testis was significantly correlated with the number of Leydig cells per testis $(r=0 \cdot 81$; $P<0.01)$.

Intratesticular testosterone content was correlated with serum concentrations of LH $(r=0 \cdot 34$; $P<0.01)$, serum testosterone $(r=0.63 ; P<0.01)$, and with number of Leydig cells per testis $(r=0.46 ; P<0.01)$. Serum FSH concentration was not $(P>0.05)$ related to intratesticular testosterone content, SER/testis, or number of Leydig cells per testis. The number of Leydig cells per testis was correlated with serum concentrations of prolactin $(r=0.22 ; P<0.05)$ and of testosterone $(r=0.26 ; P<0.05)$, but not with LH or FSH serum concentrations.

\section{Discussion}

The lack of seasonal change in composition of Leydig cell cytoplasm (Table 2) is consistent with similar size of individual Leydig cells and qualitative evaluation of Leydig cell ultrastructure between seasons in stallions (Johnson \& Thompson, 1986). Given no seasonal influence of size of individual Leydig cells or cytoplasmic composition, the seasonal differences in Leydig cell SER per testis was largely a function of differences in Leydig cell number (Table 1). Indeed, these two measures had the highest correlation coefficient of any two characteristics in the present study.

Intratesticular testosterone content was related to seasonal changes in Leydig cell number and volume of SER per testis. Further, serum concentrations of testosterone were significantly related to intratesticular testosterone content.

Given that the percentage of Leydig cell SER amongst species almost totally explained the variation in the in-vitro production of testosterone per $\mathrm{g}$ tissue in testes maximally stimulated with LH (Zirkin et al., 1980), significant correlations between the volume of SER per testis and serum concentrations of testosterone or intratesticular testosterone content were expected.

Seasonal variations in testicular weight and volume of Leydig cells in classical seasonal breeders have been associated with hypertrophy of individual Leydig cells in lump-nosed bat (Pearson et al., 1952), roebuck (Short \& Mann, 1966), and rock hyrax (Neaves, 1973). In stallions, hyperplasia rather than hypertrophy characterizes seasonal differences in volume of Leydig cells (Johnson \& Thompson, 1986) as well as seasonal differences in volume of SER per testis (Table 1).

The lack of seasonal influence in the size (Johnson \& Thomson, 1986) or cytoplasmic composition of individual Leydig cells (Table 2; Fig. 1) in stallions may be related to their continued production of spermatozoa throughout the year (Thompson et al., 1977; Johnson \& Thompson, 1983). Unlike the apparent all-or-none response to spermatogenesis of more classical seasonal breeders such as the rock hyrax (Neaves, 1973), at least some functional Leydig cells in the non-breeding season are needed in the stallion to maintain spermatogenesis throughout the year.

This study did not address the dilemma of the source (mitosis or differentiation) or fate (cell death or dedifferentiation) of the greater number of Leydig cells in the breeding season of stallions. We do know that numbers of Leydig cells increase and decrease gradually throughout the year (Johnson \& Thompson, 1986). Autoradiographic studies of adult hamsters (Johnson et al., 1987) have revealed that new Leydig cells are continually recruited to the existing population in active and reactivating testes without change in the total number of Leydig cells. Seasonal changes in numbers of Leydig cells in stallions may be accomplished by altering the rate of recruitment in 
relation to the rate of cell loss. Regardless of the source and fate of Leydig cells, the stallion exhibits seasonal variation in volume of SER/testis and probably intratesticular testosterone content by seasonal alteration of the number of Leydig cells.

We thank the Beltex Corporation, 3801 North Grove, Fort Worth, Texas 76106, for kindly providing horse tissues and Jenifer Ratliff and Maria Barletta for technical assistance. This study was supported in part by grant HD 16773 from NIH.

\section{References}

Berndtson, W.E., Pickett, B.W. \& Nett, T.M. (1974) Reproductive physiology of the stallion. IV. Seasonal changes in the testosterone concentration of peripheral plasma. J. Reprod. Fert. 39, 115-118.

Chalkley, H.W. (1943) Method for quantitative morphologic analysis of tissues. J. natn. Cancer Inst . 4, 47-53.

Ewing, L.L., Zirkin, B.R., Cochran, R.C., Kromann, N., Peters, C. \& Ruiz-Bravo, N. (1979) Testosterone secretion by rat, rabbit, guinea pig, dog and hamster testes perfused in vitro: correlation with Leydig cell mass. Endocrinology 105, 1135-1142.

Gay, V.L. \& Kerlan, J.T. (1978) Serum LH and FSH following passive immunization against circulating testosterone in the intact male rat and in orchiectomized rats bearing subcutaneous silastic implants for testosterone. Archs Androl. 1, 257-266.

Gebauer, M.R., Pickett, B.W. \& Swierstra, E.E. (1974) Reproductive physiology of the stallion. II. Daily production and output of sperm. J. Anim. Sci. 39, $732-736$.

Johnson, L. (1985) Increased daily sperm production in the breeding season of stallions is explained by an elevated population of spermatogonia. Biol. Reprod. 32, 1181-1190.

Johnson, L. \& Neaves, W.B. (1981) Age-related changes in the Leydig cell population, seminiferous tubules, and sperm production in stallions. Biol. Reprod. 24, $703-712$.

Johnson, L. \& Thompson, D.L., Jr (1983) Age-related seasonal variation in the Sertoli cell population, daily sperm production and serum concentrations of follicle-stimulating hormone, luteinizing hormone and testosterone in stallions. Biol. Reprod. 29, 777-789.

Johnson, L. \& Thompson, D.L., Jr (1986) Seasonal variation in the total volume of Leydig cells in stallions is explained by variation in cell number rather than cell size. Biol. Reprod. 35, 971-979.

Johnson, L., Amann, R.P. \& Pickett, B.W. (1978) Scanning electron and light microscopy of the equine seminiferous tubule. Fert. Steril. 29, 208-215.

Johnson, L., Matt, K.S., Bartke, A., Nguyen, H.B. \& Le, H.T. (1987) Effect of photoperiod on the size of the Leydig cell population and the rate of recruitment of
Leydig cells in adult Syrian hamsters. Biol. Reprod. 37 (in press).

Neaves, W.B. (1973) Changes in testicular Leydig cells and in plasma testosterone levels among seasonally breeding rock hyrax. Biol. Reprod. 8, 451-466.

Pearson, O.P., Koford, M.R. \& Pearson, A.K. (1952) Reproduction of the lump-nosed bat (Corynorhinus rafinesquei) in California. J. Mammal. 33, 273-320.

Short, R.V. \& Mann, T. (1966) The sexual cycle of a seasonally breeding mammal, the roebuck (Capreolus capreolus). J. Reprod. Fert. 12, 337-351.

Sokal, R.R. \& Rohlf, F.J. (1969) Biometry. W.H. Freeman and Co., San Francisco.

Thompson, D.L., Jr \& Johnson, L. (1987) Effects of age, season and active immunization against estrogen on serum prolactin concentrations in stallions. Domestic Anim. Endocrin. 4, 17-22.

Thompson, D.L., Jr, Pickett, B.W., Berndtson, W.E., Voss, J.L. \& Nett, T.M. (1977) Reproductive physiology of the stallion. VIII. Artificial photoperiod, collection interval and seminal characteristics, sexual behavior and concentrations of $\mathrm{LH}$ and testosterone in serum. J. Anim. Sci. 44, 656-664.

Thompson, D.L., Jr, St. George, R.L., Jones, L.S. \& Garza, F., Jr (1985) Patterns of secretion of luteinizing hormone, follicle stimulating hormone and testosterone in stallions during the summer and winter. $J$. Anim. Sci. 60, 741-748.

Thompson, D.L., Jr, Johnson, L., St. George, R.L. \& Garza, F., Jr (1986) Concentrations of prolactin, luteinizing hormone and follicle stimulating hormone in pituitary and serum of horses: effect of sex, season and reproductive state. J. Anim. Sci. 63, 854-860.

Wiesner, L.M. \& Kirkpatrick, J.F. (1975) Seasonal and diurnal testosterone in wild stallions. Biol. Reprod. 13, Suppl. 1, 93, Abstr. 101.

Zirkin, B.R., Ewing, L.L., Kromann, N. \& Cochran, R.C. (1980) Testosterone secretion by rat, rabbit, guinea pig, dog, and hamster testes perfused in vitro: correlation with Leydig cell ultrastructure. Endocrinology $107,1867-1874$.

Received 5 February 1987 